\title{
The Cyprus Issue: Reflection on TRNC
}

\author{
Md. Ataur Rahman Biswas**
}

\section{Introduction}

Cyprus is a Eurasian island country located in the Eastern Mediterranean Sea, east of Greece, south of Turkey, west of Syria and Lebanon and north of Egypt. Cyprus is the third largest island in the Mediterranean Sea. The earliest known human activity on the island dates back to around the 10th millennium BC. At a strategic location in the Middle East, Cyprus has been occupied by several major powers, including the empires of the Hittites, Assyrians, Egyptians, Persians, Rashidun and Umayyad Arab caliphates, Lusignans, Venetians, and Ottomans. Settled by Mycenean Greeks in the 2nd millennium BCE, the island also experienced long periods of Greek rule under the Ptolemaic Egyptians and the Byzantines. In 333 BC, Alexander the Great conquered the island from the Persians. The Ottoman Empire conquered the island in 1571 and it remained under Ottoman control for over three centuries. It was placed under British administration in 1878 until it was granted independence in 1960, becoming a member of the Commonwealth the following year. In this paper an attempt is made to discuss the details about the Turkish Republic of Northern Cyprus (TRNC) commonly called Northern Cyprus, which is a selfdeclared state that comprises the northeastern part of the island of Cyprus recognized only by Turkey and the problems associated with it.

\section{Geography}

Northern Cyprus extends from the tip of the Karpass Peninsula in the north east, westward to Morphou Bay and Cape Kormakitis (the Kokkina/Erenköy exclave marks the westernmost extent of the area), and southward to the village of Louroujina or Akıncilar. Cyprus is the third largest island in the Mediterranean Sea, after the Italian islands of Sicily and Sardinia. It is also the

\footnotetext{
* Professor, Department of Islamic History and Culture, University of Dhaka.
} 
world's 81 st largest by area and world's 49 th largest by population. It lies between latitudes $34^{\circ}$ and $36^{\circ} \mathrm{N}$, and longitudes $32^{\circ}$ and $35^{\circ}$ E. This strategic position at the junction where Europe, Asia and Africa meet has made it in its 4,000-year recorded history "a battlefield of the Near East and the prey of contending faiths and rival empires" and thus a "meeting place of races and tongues" (Luke 1957:28). A buffer zone under the control of the United Nations stretches between Northern Cyprus and the rest of the island and divides Nicosia, the island's largest city and capital of both states.

\section{Historical Background}

The arrival of the first humans correlates with the extinction of the dwarf hippos and dwarf elephants. Water wells discovered by archaeologists in western Cyprus are believed to be among the oldest in the world, dated at 9,000 to 10,500 years old. The remarkably well-preserved Neolithic village of Khirokitia is a UNESCO World Heritage Site dating to approximately 6800 BC. The island was part of the Hittite empire during the late Bronze Age until the arrival of two waves of Greek settlement (Carol G. \& Conant 2005: 121-122). When the Roman Empire was divided into Eastern and Western parts in 395, Cyprus became part of the East Roman, or Byzantine Empire, and would remain part of it until the Crusades some 800 years later. In 1570, a full scale Ottoman assault with 60,000 troops brought the island under Ottoman control, despite stiff resistance by the inhabitants of Nicosia and Famagusta. 20,000 Nicosians were put to death, and every church, public building, and palace was looted. The previous Latin elite was destroyed and the first significant demographic change since antiquity took place when Ottoman Janissaries were settled on the island.

In 1878 the island came under British administration although formally remaining under Ottoman sovereignty; under the terms of the Congress of Berlin. British rule produced new grievances, which together with a greater freedom of expression (at least initially) encouraged the growth of nationalism (Katsionis 1996: 72-77). Under the terms of British-Ottoman defense agreement, Turkey agreed to assign Britain to occupy and rule 
Cyprus, though not legally possess it. According to an annex to the Convention (1 July 1878), Cyprus was to be returned to Turkey (Necatigil 1996: 3). In 1914, the British annexed the island upon entry of the Ottoman Empire into the Great War I against the Allies. Moreover, one year later the British offered Cyprus to Greece as an inducement to enter World War I on its side. King Constantine of Greece, however, declined and the offer was withdrawn (Hill 1952: 97). However, Turkey did not recognize this until the Treaty of Lausanne in 1923.

\section{Turkish Nationalism in Cyprus}

In the meantime, the vast Ottoman Empire with its ethnically diverse population was trying to resist the centripetal forces of ethno-nationalism threatening to dismantle it from within. The millet system on which the Empire's rule had rested contained the seeds of its own destruction. With the reforms of the Tanzimat (reconstruction) era after 1839, the Ottoman rulers had embarked on a nation-building project of their own in an attempt to transform the empire into a state modeled on Western examples. This ideology, known as Ottomanism, envisaged a common Ottoman identity based on the equality of all ethno-religious groups in the Empire. However, the growth of nationalism among subject populations was unstoppable and continued to spread throughout the Balkans. Another development was the emergence of nationalism among the Muslim subjects of the Empire, including a pan- Islamist movement and later a pan-Turkish movement. The conflict of rival nationalisms culminating in the outbreak in 1912 of the Balkan Wars virtually brought about the end of the Ottoman Empire. In its wake, a narrower Turkish nationalism emerged in the 1920s, linked to the venture of the founding of the Empire's successor state, the Turkish Republic. When the Republic of Turkey was founded in 1923, Cyprus had already been severed from the Ottoman Empire for several years. Although excluded from the Turkish nationbuilding project, the Muslim Cypriot community gradually embraced the ideology of Turkish nationalism. Similar to the way Greek nationalism had been espoused by the Orthodox Cypriots some hundred years earlier, Turkish nationalism developed among the island's Muslim community in the 1930s. At the core of this nationalism were the 'Kemalist' values of secularism, 
modernization and Occidentalism. These and the British loyalists contended for the leadership of Muslims in Cyprus, as it became evident in the elections of the community's representatives to the Legislative Council. However, these internal differences were increasingly overshadowed by the need to counter the demands of the Greeks in Cyprus for enosis.

\section{The Greek Cypriot Activities of Enosis}

After World War I the intensity of Greek Cypriot demands for enosis (the movement of the Greek-Cypriot population to incorporate the island of Cyprus into Greece) continued to rise and gradually became more organized with the aim of gathering larger popular support. The Turkish Cypriots on the other hand were watching this development with suspicion and fear. Their leaders attempted to voice their opposition to enosis whenever they had a chance.

In October 1931, against a backdrop of economic crisis and general world recession, a British proposal to raise taxes ignited the flames of revolt in Cyprus. A series of riots throughout the island by crowds of Greek Cypriots crying for enosis resulted in several deaths and the burning down of the British Government House in Nicosia. The Legislative Council was abolished. In an effort to counteract the leading role played by the Orthodox clergy in the nationalist movement, two bishops were deported. Also, until 1946 the election of archbishop was made subject to the governor's approval (when, two years after the revolt, the archbishop died, the Greek Cypriots were prevented from electing a successor; the position was to remain vacant until 1947) (McHenry 1987: 79-114). The retributions only helped to intensify Greek Cypriot opposition to British rule, and brought the nationalist movement more exclusively under the patronage of the Greek Orthodox Church of Cyprus (Stavrinides 1976:19-20).

After the riots the British imposed further harsh measures to quell nationalist mobilization in the colony. Military reinforcements were dispatched to the island, press censorship was imposed and political parties proscribed. Although the island's Turks had not taken part in the disorders of 1931, the measures applied also to them. Bans were instigated against the formation of nationalist 
groups, the teaching of Greek and Turkish history was curtailed, the flying of the Greek and Turkish flags and the public display of portraits of Greek and Turkish heroes were forbidden. In World War II, Cypriots, Turks and Greeks alike, supported the Allied cause. More than 30,000 participated in the war efforts. In reward, the British rule became more lenient. Some of the restrictions were lifted and permission was granted to form political parties. In 1943, municipal elections were again held, the first time since the crackdown of 1931 (Nancy1978: 31).

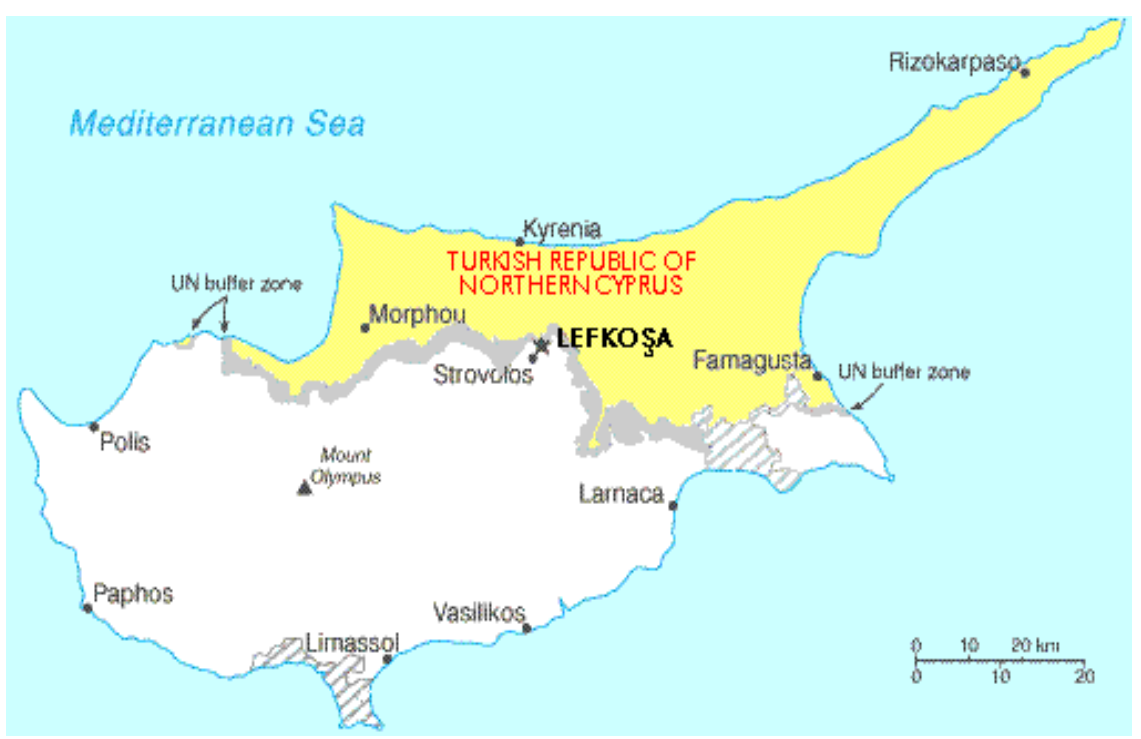

\section{Separation of Cyprus}

Contrary to the widely believed, misleading information that the island was divided after the Turkish intervention in 1974 (Birand 1985:17) the truth is that the island was divided in 1958 (Foley 1964: 142). April 1, 1955 saw the foundation of EOKA (National Organization of Cyprus Fighters), which was not actually seeking independence as it claimed. If that had been the case, the Turkish Cypriots on the island and Turkey would have accepted this. EOKA's goal was "Enosis", union with Greece (Grivas 1964:3), even though the Greek mainland is $800 \mathrm{~km}$ away to the west, however the Turkish coast is only $75 \mathrm{~km}$ away north bounds. 
Neither the Turkish Cypriots nor Ankara accepted Enosis and eventually the island, after inter-communal clashes, divided initially in 1958 (Stavrinides 1975:34). The division was ossified during the December 1963 events and the "Green Line" was drawn by Colonel Peter Young (Oberling 1982: 98-99), the then commander of the British troops in the island, with a green pencil on the map. After the severe inter-communal clashes, the UN troops finally set foot on the island in May 1964, after UN Security Council Resolution No. 186 was adopted on March $4^{\text {th }}$, 1964. The division between the two people of the island was also distinctive in the social life. No intermarriages took place for centuries and still the same. It is almost banned by the 1960 Constitution of Cyprus Republic. The Turkish Cypriots lost (Denktash 1988: 26-29) thousands of their kinsmen and women. They also lost their hopes, their future, their past and lived under inhuman conditions with no food, no water, no home, no electricity, no money, no jobs and no hope for the future, under the genocide exerted by the then Makarios Government during the dark ages, which lasted from 1963 to 1974. The island was invaded by the Greek army of Greece from 1964 to 1967 and severe clashes took place between Turkish Cypriots and Greek Cypriots backed with the troops from Greece. Finally, the Security Council, at a meeting on 22 December 1967, adopted resolution 244 (1967) calling Greek national troops to be withdrawn from Cyprus. This withdrawal never fulfilled completely and the consequences of it was the July 15, 1974 Coupe de Eta against Makarios by the Greek soldiers and officers remained in the island (Oberling 1982:144-145).

\section{Unresolved TRNC Issue}

There is no instrument to motivate the Greek-Cypriots on the negotiation table. At this crucial stage, the mission that should be fulfilled by the EU has never been understood by the member countries or the Union itself. This ineffectiveness forced the negotiations for a comprehensive solution to the Cyprus problem, which ended up unsuccessful and played a significant role in the victory of Mr. Eroglu. But even today, a forward step towards the lifting of the embargoes and to fulfill the post-2004 promises of the EU and others, on "Direct Trade" for the Turkish Cypriots would 
be quite an important step towards the solution and may be meaningful and operable. The only way to break down the existing belief of Turkish Cypriots that the EU is not earnest and made a phony promise just to give support to a certain Turkish Cypriot politician would be this forward step. This step would compel and motivate the Greek Cypriots towards a solution. And in the long run, if it causes an increase in the eastern Mediterranean trade due to the opening of the Turkish air and sea ports to the vessels and planes bearing the flag of the Cyprus Republic, it may give a significant push to the creation of confidence between the two peoples of Cyprus. This is one of the very important points which is desperately needed in Cyprus. The obverse of the presidential elections looks quite different. If the result of this election is analyzed in depth, it can be easily understood that the victory of Mr. Eroglu will be a constructive factor to a comprehensive and sustainable solution to the Cyprus problem. Ethnic clashes and the breach of peace actually took place among the nationalists of both Greek and Turkish Cypriots of the island. To reach a sustainable and a long lasting comprehensive solution, peace is needed in between the nationalists of both people. It was merely impossible for Mr. Talat to accomplish this mission. On the other hand Mr. Eroglu is quite a dependable character for the Turkish Cypriot nationalists and this distinction will add leverage to a solution to the Cyprus problem, in the Turkish side. It will be quite deceptive to popularize the "Who said No to Annan Plan" matter. Even when evaluating the case from this popularized understanding, the outcome will inevitably be Mr. Christofias voted "NO" to this plan and now for a solution alike to Annan Plan, there are 'two NO voters' on the negotiation table".

\section{What EU May Do?}

The AK Party (Justice and Development Party) government of Turkey in power since 2002, is nearly three steps ahead of Greece and Greek Cypriots. By opening up five check points for free passage on April 23, 2003, supporting the Annan Plan on April 24, 2004 and encouraging the then president of TRNC, Mr. Talat to work for a compromise in the ongoing negotiations, initially with Mr. Papadopulos and then Mr. Christofias. The EU should exert pressure on Greek Cypriots and Greece, who seem reluctant since 
the beginning of the talks in1968. To lessen the mistrust between the two peoples of Cyprus, the EU should organize an international conference inviting the two peoples of the island and their motherlands, all on an equal basis, to initiate a process to settle the everlasting Cyprus Dispute. The European Parliament should follow the lead of the European Commission and start work to fulfill the EU's April 2004 promise of "Direct Trade" for the Turkish Cypriots. Passing this regulation may lead to a further constructive step by Turkey to open its seaports and airports to Cypriot vessels and planes, and the European Union would then lift the Cyprus-related blocks on eight of Turkey's EU negotiating chapters. This will end the constrained vicious circle and build good relations with Turkey.

These precautions will give a push to the negotiations pushing them towards a sustainable solution. If the EU cannot exert pressure on the Greek Cypriot side for a comprehensive solution on the ongoing negotiations, then a significant partition in the island will be inevitable. Turkey will be faced with a frozen process with the EU and turn its face towards the East rather than the West, and EU-NATO relations will never be as they have been before.

\section{Conclusion}

The division of Cyprus is commonly referred to as 'the Cyprus problem.' At the heart of this problem is the division of the islands into Greek and Turkish zones. Attempts to resolve the Cyprus problem and reunify the island have undergone various levels of negotiation for over 45 years. Talks between Greek and Turkish Cypriot leaders have thus far failed to reach a mutually agreed settlement leaving the country with a solution for unification far from being achieved and raising the specter of a possible permanent separation. Since the beginning of 2011, Cyprus President, Demetris Christofias, and Turkish Cypriot leader, Dervis Eroglu, have continued the negotiation process even though the talks appear to have increasingly exposed differences and frustrations between the two leaders. On July 7, 2011, Christofias and Eroglu traveled to Geneva to meet for a third time with U.N. 
Secretary-General Ban Ki-moon in another attempt by the U.N. to boost momentum for the talks. It appears that Ban insisted that the negotiations conclude by October so that an international conference could be held to discuss security issues and that referenda could be scheduled in both the north and south by the spring of 2012. The hope among some is that a reunified Cyprus can assume the rotating presidency of the EU on July 1, 2012.

In mid-July, Turkish Prime Minister, Erdogan, on a visit to northern Cyprus, warned that an agreement needed to be achieved by the end of 2011 or the island could remain split and stated that no territorial compromises, including the return of Varosha or Morphou to Greek Cyprus, would be acceptable. He also stated that Turkey would essentially freeze its relations with the EU during the Cypriot presidency of the EU if there were no solution to the Cyprus issue because Ankara could not accept the presidency of South Cyprus, which it does not recognize. These comments led Cypriot President Christofias to state that there could be no prospect for peace if this was also the position of the Turkish Cypriots.

\section{References}

Birand, M. A. 1985. 30 hot days, Oxford University Press: Oxford, UK.

Carol, G. T. \& Conant, C. 2005. The Trojan War, Greenwood Publishing Group.

Denktash, R. R. 1988. The Cyprus Triangle, K. Rustem \& Brother: London.

Foley, C. 1964. The Memoirs of General Grivas, Longmans: Suffolk, UK.

Grivas, G. 1964. Guerrilla Warfare and EOKA's Struggle, Longmans, London, UK.

Hill, S. G. 1952. History of Cyprus, volume iv, Cambridge University Press: Cambridge. 
Katsionis, R. 1996. Labour, Society and Politics in Cyprus during the Second Half of the Nineteenth Century. Cyprus Research Centre: Nicosia.

Luke, Sir Harry. 1957. Cyprus, A Portrait and an Appreciation, Rustem and Harrab: London.

McHenry, J. A.1987. The Uneasy Partnership on Cyprus, 19191939. Garand Publishing. Inc.: New York and London.

Nancy, C. 1978. The Cyprus Revolt, George Allen \& Unwin: London.

Necatigil, Z. M. 1996. The Cyprus Question and the Turkish Position in International Law, Oxford University Press.

Oberling, P. 1982. The Road to Bellapais, Columbia University Press: New York.

Stavrinides, Z. 1975. The Cyprus Conflict, Loris Catranides Press: Nicosia, Cyprus.

Stavrinides, Z. 1976. The Cyprus Conflict: National identity and Statehood, Nicosia. 